Who Walks Through the Revolving Door?

Examining the Lobbying Activity of Former Members of Congress

\author{
Jeffrey Lazarus \\ Georgia State University \\ j.lazarus@gsu.edu \\ Amy McKay \\ University of Exeter \\ A.McKay@exeter.ac.uk \\ Lindsey Herbel \\ Georgia State University \\ 1herbel1@student.gsu.edu
}

\begin{abstract}
:
Government watchdog groups and the government itself have shown concern about the "revolving door" of employees moving from Congress to private lobbying organizations. As of yet, the academic literature analyzing who becomes a revolving door lobbyist is small but growing. We contribute to this literature by examining which former members of Congress become lobbyists. We construct a dataset of all members of Congress who left the institution between 1976 and 2012, identifying those who go on to register as lobbyists. We observe several trends. Among these: there is not a significant difference in the rates at which former House members and senators become lobbyists; institutional standing (in the form of party leadership and other such positions) has a profound effect on which former House members become lobbyists, but less so among former senators; and there is some evidence that Republican former senators are more likely to become lobbyists than Democratic former senators, but this party difference is virtually absent among former House members.
\end{abstract}


In the context of lobbying, the phrase "revolving door" refers to the phenomenon of highlevel government employees - including members of Congress, the staffers who work for them and members of the executive branch - leaving their jobs in government and becoming lobbyists. As lobbyists, former policymakers and their employees attempt to influence current policymakers - those who were, until recently, the newly minted lobbyists' colleagues. This trend is disconcerting to many political observers because people who leave government to become lobbyists may provide their new employer unusually good access to their former colleagues or they may carry to the private sector insider information about government operations that gives them an unfair advantage in their lobbying efforts (e.g., Holman 2007; Leech 2013).

Various scholars have studied the "revolving door" since Gormley (1979) initially examined the behavior of FEC commissioners who had previously worked in the broadcast industry. In response to the recent acceleration of Congress members and congressional staff becoming lobbyists, however, focus on the topic has increased (e.g., Vidal et al 2012, LaPira and Thomas 2014, Baumgartner et al 2009). This article adds to the growing body of research by asking which former members of Congress are most likely to become lobbyists. Specifically, we identify all members of Congress who left the chamber between 1976 and 2012 and observe which ones subsequently registered with the House and Senate as a lobbyist. We estimate this variable in order to understand the effect various factors have on members' propensity to become lobbyists. These factors include members' institutional position in the Congress, ideology, and the time they depart Congress. Our results indicate that institutional position has a significant effect on which Congress members become lobbyists, although the effect is stronger and more consistent in the House than in the Senate. Party membership and ideology have significant 
effects, although not consistently and not always in the manner we predict. Finally, in addition to the main analysis, we take a closer look at those members of Congress who become lobbyists, examining whom they work for upon leaving office and how long they wait after leaving Congress to begin lobbying.

\section{The Revolving Door}

Congressional experience is highly valuable to those who make a living trying to persuade members and their staff. Working on Capitol Hill gives employees an understanding of the multiple and competing demands placed on congressional offices, knowledge about which arguments are likely to be most effective with members, a sense of where to draw the ethical line, and especially for legislative assistants, policy expertise. Additionally, former members and staffers are more likely to know important details, such as which staffers are pivotal on a given issue, personal information about members and senior staff that may be the key to initiating a conversation or professional relationship, and members' true opinions on specific issues (as opposed to the preferences they choose to reveal to constituents or party leaders).

Those who fear "the revolving door" are primarily concerned about this kind of personal information: Is it fair that some lobbyists have an ongoing relationship with a member of Congress that they can leverage to learn the member's true feelings about the issue of the day? Former staff members can maintain connections to their former office and beyond, such as their bosses' committees and staffers from other offices within the state delegation. For their part, former members of Congress know just where to go to run into current members, and if they can avoid registering as a lobbyist, ${ }^{1}$ they can frequent the members-only gym and even the chamber floor. 
Recent studies suggest that lobbying firms may be motivated to hire revolvers primarily to pursue access. Vidal et al (2012) find that the salaries of staffers-turned-lobbyists vary with the fates of their former congressional employers: lobbyists with previous experience in a Senate office see a 24 percent decrease in income when the senator for whom they formerly worked leaves the chamber. LaPira and Thomas (2014) find that revolvers tend to have clients from a more diverse set of economic sectors than nonrevolvers, which - given the extensive network of personal and professional connections which come from working in Congress - suggests that they are hired primarily for access rather than policy expertise. Bertrand et al (2011) argue that lobbying is driven more by personal connections than by expertise, although lobbyists themselves argue that their personal connections are less important than their substantive knowledge (Salisbury et al. 1989; Heinz et al 1997). Indeed, access and expertise are not mutually exclusive - lobbying firms may be motivated by either consideration or both when hiring a revolver. Moreover, the revolvers who provide the highest-level expertise are also likely those who provide the best access, making it difficult to distinguish the two motives. Thus, in this paper we are agnostic as to which motivation, if either, is dominant.

A separate but related strand of recent research indicates that revolving door lobbyists can shape policy outcomes. In a broad survey of issue areas, Baumgartner et al (2009) find that hiring “covered officials" systematically predicts a lobbying campaign's success. More narrowly, Lazarus and McKay (2012) find that universities that hire revolving door lobbyists are more likely to secure funding via earmarks than those that lobby but do not hire such lobbyists.

Many questions arise surrounding the normative aspects of revolving door lobbying. Is it ethical to use social ties to a members or congressional staff to advance a lobbyist's agenda? In a pluralist setting in which multiple groups exist on each side of a given issue, what are the 
consequences if lobbyists on one side have greater inside access than lobbyists on the other side? More pointedly, in the many cases where this pluralist idea falls short and interest group access is not equal on all sides of an issue, to what extent are revolving door lobbyists to blame for the inequality?

Congress itself appears to take these concerns seriously, as evidenced by several laws and rules governing the post-congressional employment of former Members and staff (see Cain and Drutman 2014). For example, members and staff must report outside job negotiations to the House or Senate Ethics Committee, former members of Congress who register to lobby lose their access to the chamber floor and other areas of the Capitol, staff are restricted from lobbying their former offices for one year, and registered lobbyists must disclose their former employment by Congress. Unfortunately these requirements may make the problem worse, as they give revolving door lobbyists an incentive not to register at all.

Recent studies are creating a more accurate picture of the revolving-door population than has previously been available (Cain and Drutman 2014, LaPira and Thomas 2014). In this article, we take a narrow analytical focus and ask specifically, which members of Congress are most likely to lobby upon retirement?

\section{Who Goes Through the Revolving Door?}

We construct a dataset consisting of all members of Congress who left the institution between 1976 and 2012. ${ }^{2}$ Overall, 25 percent of the 1275 House members and 29 percent of the 254 senators in our dataset go on to register as lobbyists. Figures $1 \mathrm{a}$ and $1 \mathrm{~b}$ provide some context as to how those members are distributed throughout the time period. Figure 1a presents the number of House members and senators leaving their respective chambers in each year. The 
number of departures varies over time: there is more variation in the House than in the Senate, but the figures show no overall time trend in either chamber. House departures peak in the redistricting years 1982 and $1992^{3}$ and the rate swings dramatically between highs near 120 and lows of 40 departing members in a given year. Figure $1 \mathrm{~b}$ presents the percentages of members departing from each chamber each year who have since registered as lobbyists. In both chambers, the overall trend is decidedly positive: over time the share of members becoming lobbyists is growing.

In our main analysis, we examine six sets of factors that may affect the probability that a former member of Congress becomes a lobbyist. First is the atheoretical issue of time. Moving through the revolving door is a growing phenomenon. The first examples are seen in the 1970s (Center for Responsive Politics 2014) and the phenomenon becomes prevalent in the 1990s. Generally, we expect to find that members are more likely to become revolvers the more recently they left the House or Senate.

Second, we look at the member's chamber. Although the House and Senate as legislative bodies are roughly equivalent in authority in the political system, individual senators are more powerful than individual House members. Beyond the relative size of the chambers, senators have stronger procedural rights than House members, giving them more power to block, and thereby influence, legislation (e.g., Binder and Smith 2001, Koger 2010, Smith 2014). Because of this imbalance, former senators may well offer more potential power to prospective lobbying firm employers and clients than do former House members. Thus, we predict that former senators are more likely to become lobbyists than former House members.

Third, in both chambers, certain institutional positions confer great amounts of authority, and members of Congress who hold these positions may offer future lobbying employers more 
access or expertise than "backbenchers" with no special position. We posit that the more institutional authority someone accrues while a member of Congress, the more likely she or he is to become a lobbyist. More powerful members may be seen by potential employers as more likely to become central to networks of other powerful legislators, thus providing better access. As well, they are more likely to have highly detailed, specialized knowledge of how the legislative process works. From the former members' perspective, those possessing these traits can command higher salaries as lobbyists, and the higher the potential salary, the more attractive lobbying is to members, all else being equal. Thus we predict that committee chairs (Shepsle \& Weingast 1987, Ferejohn 1974), party leaders (Rohde 1991, Cox and McCubbins 1993), Appropriations committee members (Savage 1991), and members of either chamber's taxing committee (Ways and Means in the House; Finance in the Senate; Fenno 1973) are each more likely than a backbencher to become a lobbyist upon retirement. In addition, members who have spent a significant amount of time in the chamber have more opportunity to develop both relationships and expertise, and thus we expect that the likelihood of becoming a revolver correlates positively with chamber seniority.

Fourth, there are two potential ways that a member's party might influence his or her probability of becoming a lobbyist. First, in accordance with the above discussion, members of the majority party have more influence within the chamber than members of the minority party (Rohde 1990, Cox and McCubbins 1993). (This difference is more pronounced in the House than in the Senate, but it exists in both chambers.) Thus, one hypothesis associated with party membership is that members who are in the majority party when they leave become lobbyists at higher rates than those who are in the minority. On the other hand, the Republican Party is generally seen as more business-friendly than the Democratic Party, and thus Republican 
members may be more ideologically inclined to become lobbyists and/or have more opportunities extended to them. As a result, a second hypothesis associated with party is that Republicans are more likely to become lobbyists than Democrats.

Fifth, there are similarly two hypotheses associated with members' ideology. First, it could be that more conservative members are more likely to become lobbyists, per the reasons mentioned above. Simultaneously - and especially if lobbying firms are motivated by seeking access - moderate members might be more attractive to potential employees than ideologically extreme members. Moderates may have closer ties to a larger number of serving members; in other words, they might be more centrally located within the social networks lobbyists are seeking access to. Additionally, ideologically extreme members may have difficulty thinking about and discussing issues in a neutral way (or potential employers may perceive them as such), which would hamper their ability to become successful lobbyists. Thus the second ideologyrelated hypothesis is that moderate members are more likely to become lobbyists than ideologically extreme members.

Finally, how a member of Congress exits Congress may influence whether she or he becomes a lobbyist. Losing an election might make a former member less attractive to a lobbying firm or other potential employer, in a similar manner as it makes the member less attractive as a future political candidate (Jacobson 2012). Thus, we test the prediction that members who lose reelection are less likely to become lobbyists than those who retire from the chamber voluntarily.

\section{Empirical Analysis}

For our primary empirical analyses, we select all members who left the Congress between 1976 and 2012, excepting those who left as the direct result of a criminal conviction. ${ }^{4}$ We 
identify former members who become lobbyists through information collected by the Center for Responsive Politics, which organizes the data from lobbying disclosure forms into a database located at the website OpenSecrets.org. ${ }^{5}$ In the following subsection, we consider the bivariate relationships between the likelihood of a member's becoming a lobbyist and the independent variables discussed above. Then, we present multivariate logit analyses of the likelihood of former members of Congress becoming a lobbyist.

\section{Bivariate Analysis}

Figures 2 and 3 indicate the percentages of former House members and senators, respectively, who become lobbyists. In both figures, the top bar indicates the percentage over the entire group: 27 percent of former House members and 31 percent of senators have registered to become lobbyists. Although the percentage is slightly higher among former senators, as we predict, the difference is not significant $(\mathrm{p}<.190)$.

Among all the independent variables, the decade of retirement most strongly correlates with members' becoming lobbyists. Few members of either chamber who leave in the 1970s or 1980s become registered lobbyists, although the true numbers of revolvers are likely higher since prior to 1995 , registration was required only of those whose "principal purpose" was to aid in the passage or defeat of legislation through direct communication with elected Members of Congress. The numbers accelerate in the 1990s and 2000s, with more than a third of departing House members and more than 40 percent of departing senators registering in those decades. Those who leave in the 2012 election cycle are most likely to become lobbyists: half of those leaving the House and 60 percent of those leaving the Senate in that year have already registered.

In both chambers, institutional standing appears to play a strong role in determining who becomes a lobbyist. Backbenchers are least likely to become lobbyists, and party leaders are the 
most likely. In between these two extremes in both chambers are Appropriations members, Ways \& Means/Finance members, and committee chairs. In the House, all three groups are significantly more likely to become lobbyists than backbenchers; among senators, the difference between backbenchers and these other groups is substantively smaller and statistically significant for only members of Finance and Appropriations.

Closely related to institutional position is seniority. To examine seniority in Figures 2 and 3 we divide the samples into quartiles, based on years served at time of departure. The relationship between seniority and the likelihood of becoming a lobbyist is not strictly monotonic in either chamber. In the House, members in the bottom quartile are least likely to become lobbyists, with the upper three quartiles being roughly equivalent. Thus, there appears to be a threshold of House tenure that makes a member more likely to become a lobbyist, but beyond that seniority may not have an effect. In the Senate the first two quartiles are roughly equally likely to become lobbyists, while those in the third are most likely and those in the fourth least likely. This might indicate the countervailing effects of seniority and age: the median retiring senator in our dataset retires at 61 years of age, but the median among the fourth seniority quartile retires at 74. Even though greater seniority may influence departing senators' decisions to become lobbyists, many of the most senior departing senators may be ready for true retirement. We next examine the effect of party. For both chambers, Republicans are more likely to become lobbyists than Democrats. However, while the difference among former senators is both substantively meaningful and statistically significant $(p<.028)$, among former House members, the difference is much smaller and not significant $(\mathrm{p}<.17)$. Additionally, majority status appears to have no effect on who becomes a lobbyist. 
To capture ideology we use each member's DW-NOMINATE score (Poole and Rosenthal 2000) from his or her last Congress and again divide each sample into quartiles from most liberal to most conservative. ${ }^{6}$ For former House members, ideology does not have a clear effect on the likelihood of becoming a lobbyist, but a much clearer picture emerges in the Senate: conservative former senators are markedly more likely to become lobbyists than liberal former senators; indeed, nearly half of the most conservative former senators become lobbyists, which fits with the above finding that Republican former senators are more likely to become lobbyists than Democratic former senators.

We also take the absolute value of members' DW-NOMINATE scores to examine the effects of ideological extremity (again dividing departing members into quartiles). Here there is a clearer pattern in the House, although it is the opposite of what we predict. Among the first three quartiles, the more ideologically extreme a member is the more likely he or she is to become a lobbyist. This trend drops off in the fourth quartile of extremism, suggesting that the most extreme members might have trouble finding lobbying jobs. Among former senators, there is no clear pattern between ideological extremism and becoming a lobbyist.

Finally, losing an election does not appear to affect a member's likelihood of becoming a lobbyist; the effect is neither statistically significant nor consistent between the two chambers.

\section{Multivariate Analysis}

In this section, we present the results of multinomial estimations of the decision by former members of the House and Senate to become lobbyists, examining the same group of departing members as in the above bivariate analyses. The dependent variable being dichotomous, we employ logit as our estimator. The specification of our independent variables 
is guided both by theories about what makes a member more likely to become a lobbyist (discussed previously) and, at the margins, the results of the bivariate analysis presented above.

To estimate the decision to become a lobbyist, we employ the following independent variables. Lost last election is used only in the House models. It is a dummy variable coded 1 if the member left Congress because she lost her last election campaign and 0 if she retired voluntarily. Democrat is a dummy variable coded 1 if the member is a Democrat, 0 if he is a Republican. Extremism, used in the House models, is the absolute value of each member's DWNOMINATE scores; owing to the nature of the relationship identified in Figure 2 we also include extremism squared. (Because extremism is bounded by 0 and 1 , we perform a linear transformation on the variable by adding 1 . This shifts it to the right on the number line, and provides the traditional relationship between the variable and its square.) Based on the bivariate results, DW-NOMINATE (Poole and Rosenthal 2000) is used in the Senate models instead of extremism. Dummy variables indicate whether each member is a committee chair, party leader, a member of the Ways \& Means committee, and a member of the Appropriations committee; the comparison group is backbenchers. ${ }^{7}$ We also include the number of years of seniority each member has in his or her chamber (logged). Finally we include as control variables members' age as well as age squared owing to the decreased likelihood of career shifts happening as former members get older. Finally, we include a year counter to account for the passage of time. Table 1 presents descriptive statistics of the (untransformed) variables.

Table 2 presents the results for former House members. We present three estimations. Column 1 presents the estimation of the full sample, while Columns 2 and 3 present results of the equation estimated with just Democrats and just Republicans, respectively. In Column 1, nearly every coefficient is statistically significant in the direction indicated by Figure 2 . The two 
exceptions are lost last election and Democrat. Aside from these two variables, the results confirm that even when controlling for other influences, each independent variable remains significantly related to the probability of a House member becoming a lobbyist. Extremism is positive and significant, while extremism squared is negative, corroborating the pattern found in the bivariate analysis. Each of the four dummy variables that indicate members' institutional positions is positive and significant. Notably, so is seniority. This is interesting because party leaders, chairs, and members of important committees typically have higher levels of seniority than other members; it could have been the case that either position or seniority causally drove the other's empirical correlation with becoming a lobbyist. However, these results indicate that position and seniority both contribute to the decision to become a lobbyist. Finally, the control variables are statistically significant as well: age has a concave relationship with the probability of becoming a lobbyist, and the year counter is positive and strongly significant.

The single-party results presented in Columns 2 and 3 indicate several important differences between Democratic and Republican former House members. Among Democrats, institutional position appears to play less of a role in determining who becomes a lobbyist, as only Ways \& Means is significantly related to the dependent variable. Extremism (used here as a linear variable, since within each party extremism takes on a monotonic quality, as ideology varies from moderate to conservative or liberal) is not significant either. However, seniority and age are significantly related to whether a former member becomes a lobbyist. Among Republicans, extremism, institutional standing, and seniority are all significant factors. The coefficient on extremism is negative and significant, indicating that as extremism scores get higher and members get more ideological (conservative) they are less likely to become lobbyists. The institutional standing variables and seniority are, once again, positive and significant. 
Table 3 presents similar models, this time examining former senators. There are two changes, both following the bivariate results discussed above. First, we replace extremism and extremism squared with the singular variable DW-NOMINATE. Note that the untransformed DW-NOMINATE is highly correlated with party; however, results are substantively unchanged when either DW-NOMINATE or Democrat is excluded from the model. Second, in addition to seniority we include seniority squared. Once again, Column 1 presents the results for the full sample, Column 2 presents Democrats, and Column 3 presents Republicans.

Column 1 indicates fewer variables that are significantly related to senators' likelihood of becoming lobbyists. This may be due in part to the much smaller sample of former senators (here $\mathrm{N}=235$, as opposed to 1126 in Table 2). But, in addition, it may relate to the different distributions of chamber authority in the two chambers. Above we posit that the more power a member has in a chamber the more likely she is to become a lobbyist. In the House, power is concentrated in relatively few hands, making certain key individuals more important within the chamber and thus more likely to become lobbyists upon retirement. In the Senate, on the other hand, power is distributed much more evenly; for example, each individual senator is able to stop legislative action on a bill or nomination by placing a "hold" on it. Power in this chamber is thus less dependent on institutional positioning or seniority. This may explain why only one of the four institutional position variables is significant (party leader), and seniority is strongly significant and negative. (This is true even after controlling for age.) Thus institutional positioning, be it formal or informal, appears to have little to do with the probability with which a former senator becomes a lobbyist.

The same appears to be true for both party and ideology, as neither Democrat nor $D W$ NOMINATE is significant. This comes as a surprise, based on the significant bivariate 
relationship each has with the dependent variable, identified in Table 3. One potential cause of this non-finding is multi-collinearity: these two variables are correlated at $r=.85$, which may be inflating standard errors. We check for this in two ways. First, we re-run the model in Column 1, dropping first Democrat and then DW-NOMINATE. In both cases, the variable that remains in the equation is still not significantly related to former senators' likelihood of becoming a lobbyist. Second, Democrat is not included in the single-party estimations presented in Columns 2 and 3, and here DW-NOMINATE is still not significant. Thus the null finding here appears robust: when controlling for other factors, neither party nor ideology appears to explain much variation in terms of which senators become lobbyists, once other factors are accounted for.

Once again the single-party estimations reveal some differences between Democrats and Republicans. Democratic former senators appear more influenced than Republican former senators by formal institutional positions: both party leader and committee chair are positive and significant. Also, Democratic former senators are more sensitive to age than Republicans are, as both age and age squared are significant, producing a concave relationship. Among Republicans, none of the institutional position variables are significant, and neither are the age variables. In fact, the only variable significantly related to the likelihood of a Republican former senator's becoming a lobbyist is seniority: both seniority and seniority squared are significant, indicating that even after controlling for age, it is the moderately senior Republicans who are most likely to become lobbyists.

\section{Revolving Door Lobbyists: A closer look}

Using data from the Center for Responsive Politics, we record the employer for whom each member of Congress works the first time they file as a lobbyist after leaving Congress. ${ }^{8} \mathrm{We}$ code these employers into four mutually exclusive categories. The results are displayed in Table 
4; column 1 presents results for House members and column 2 for senators. Overall, revolvers from both chambers display similar patterns of employment, with only slight differences.

The result that stands out most is that strong majorities from both chambers -78 percent of House revolvers and 87 percent of Senate revolvers - work for lobbying firms upon leaving Congress. We include in this category any organization that does not lobby the government on its own behalf, but does so on behalf of paying clients, including traditional lobbying firms as well as law firms, management consulting firms, and public relations firms. An additional trend within this category was that a significant number of revolving members during this time do not go to work for previously existing firms, but instead start their own lobbying firms: 23 former senators ( 28 percent of all revolvers from that chamber) and 74 former House members ( 23 percent) start their own shops rather joining an existing one. In fact, our focus on members' first employers actually understates this trend somewhat: an additional 10 senators and 26 House members start a lobbying firm after initially lobbying for another employer. All told, 133 of the 407 revolvers in our dataset, or 33 percent, at some point start their own firms.

The remaining revolvers work as in-house lobbyists for one of three different types of organizations: for-profit corporations, trade organizations, or non-profit groups. For both chambers, the largest of these categories is non-profit (8.6 percent House, 8.5 percent Senate), ranging from universities (e.g., Bob Kerry was president of the New School for 9 years after leaving the Senate) to single-issue advocacy groups (Robert Walker lobbied for Handgun Control, Inc., after leaving the House) and broader advocacy groups (Jim DeMint worked for the Heritage Foundation after leaving the Senate). Smaller numbers of revolvers (6.8 percent House, 2.5 percent Senate) lobby for private corporations such as Blue Cross/Blue Shield (Jason Altmire), Lockheed Martin (Norman Mineta) and Bell Atlantic (Tom Tauke). Finally, the 
number of revolvers working for trade associations is similar to the number working for corporations (5.8 percent House, 2.5 percent Senate), and includes employers such as the Motion Picture Association of America (Chris Dodd) and the Association of American Publishers (Patricia Schroeder and Tom H. Allen).

We also examine the number of years that elapse between when a member of Congress leaves the chamber and when he first registers as a lobbyist. A histogram of this variable is shown in Figure 4. The majority of all revolvers begin lobbying activity either the same year they leave (shown in the figure as years $=0 ; n=98$ or 25 percent) or the next year (years $=1$; $\mathrm{n}=141$ or 36 percent). After that, the count drops off dramatically, with 29 revolvers registering after two years, and the $\mathrm{N}$ decreasing more or less steadily after that. However, the tail is quite long, with the longest wait time between service in the chamber and registering as a lobbyist being 27 years (Roger Zion, who left the House of Representatives in 1974 and set up a lobbying firm in 2001). Overall, the median number of years members wait before lobbying is 1 , and the mean is 3.14. There is no statistically significant difference between the chambers $(\mathrm{p}<.462)$.

Rules requiring a "cooling off period" during which a retired member of Congress must wait before lobbying makes it somewhat surprising that the majority of revolvers begin their lobbying activity within one year of leaving Congress. Since the passage of the Honest Leadership and Open Government Act of 2007, House members are required to wait one year and senators two years before engaging in any lobbying activity. Nonetheless, within our dataset 22 senators who leave the chamber after 2007 register to be a lobbyist either the year they leave or the following year. Similarly, 48 House members who leave the chamber after 2007 register as lobbyists in the same year they depart the chamber. At first blush, it appears that these 70 members of Congress are violating the Open Government Act in full view of the public, with 
little or no consequence. This calls into question how effective the rules governing revolvers' lobbying activity are.

\section{Discussion and Conclusion}

This article contributes to the small but growing literature that examines the revolving door phenomenon. LaPira and Thomas (2014) estimate the size of the revolving door lobbyist community, and both Baumgartner et al (2009) and Lazarus and McKay (2012) begin to assess how influential these lobbyists are. But we still have had little idea of who is most likely to become a revolving door lobbyist. This paper addresses that gap by asking the question of which members of Congress are most likely to register as lobbyists after leaving the chamber.

We find that members of the House and Senate are roughly equally likely to become lobbyists after they leave Congress. However, various factors influence the decision differently for members leaving each chamber. Among House members, formal institutional positions and seniority are very important determinants of whether a former member becomes a lobbyist. This is likely because these factors to a large extent determine members' degree of power and influence within the chamber. On the other hand, these factors matter less in the Senate, where rules of procedure produce a flatter distribution of power among senators. Additionally, there is some evidence that party and/or ideology influences the decision of whether or not to lobby after leaving the chamber: the bivariate analysis showed both that Republicans are more likely to lobby than Democrats, and that conservatives are more likely to lobby than liberals, although these relationships are not corroborated by the multivariate analysis. In the House, party does not appear to play a strong role at all, and ideology is influential not through the substance of politics but through ideological extremism: the more extreme a former member is, the more 
likely she or he is to become a lobbyist - but this is less true for the most extreme former members.

Although this article advances our knowledge of which legislators go through the revolving door, it is only a first step. Further research is needed to address several important questions, many of which concern congressional staffers. Although members of Congress have higher profiles, their numbers are dwarfed by the number of staff members who leave Capitol Hill to lobby their former employers. The next logical step is to analyze which staffers are most likely to depart and become lobbyists and which members' offices produce the most staff members who end up lobbying. Moreover, LaPira and Thomas (2014) argue that former congressional staff tend to work on a wide variety of issues, rather than specializing in a policy area-suggesting they are hired not for their expertise but for their connections. This brings the question back to members of Congress: does the same apply to members who become lobbyists?

Perhaps even more troubling from a normative perspective is the possibility that Congress members may alter their legislative behavior in their final term or session to become friendlier to the business, industry, or concern that they will lobby for (Rothenberg and Sanders 2000; Kousser, Lewis and Masket 2007). Voting records, bill introduction patterns, and committee activity are all areas which future employers may be interested in exploiting prior to when the member leaves office. Whether this occurs is yet another open question. However, to the extent that it does occur, being able to predict which members become lobbyists may help voters, journalists, and interest groups to keep these members honest while they are in office. 


\section{References}

Baumgartner, Frank R., Jeffrey M. Berry, Marie Hojnacki, David C. Kimball, and Beth L. Leech. 2009. Lobbying and Policy Change: Who Wins, Who Loses, and Why. Chicago:

University of Chicago Press.

Bertrand, Marianne, Matilde Bombardini, and Francesco Trebbi. 2011. "Is It Whom You Know or What You Know? An Empirical Assessment of the Lobbying Process." National Bureau of Economic Research Working Paper 16765.

Binder, Sarah A. and Steven S. Smith. 2001 Politics or Principle? Filibustering in the United States Senate. Brookings Institute Press.

Center for Responsive Politics 2014. "Revolving Door.” http://www.opensecrets.org/revolving/

Cain, Bruce E. and Lee Drutman. 2014. "Congressional Staff and the Revolving Door: The Impact of Regulatory Change." Election Law Journal: Rules, Politics, and Policy. 13(1): 27-44.

Cohen, Jeffrey E. 1986. “The Dynamics of the 'Revolving Door' at the FCC." American Journal of Political Science 30:689-708.

Cox, Gary W. and Mathew D. McCubbins. 1993. Legislative Leviathan: Party Government in the House. Los Angeles: University of California Press.

Foreign Agents Registration Act. 1938. 22 U.S.C. Section 611 et seq.

Fenno, Richard. 1973. Congressmen in Committees. Los Angeles: University of California Press.

Gormley, William T. Jr. 1979. "A Test of the Revolving Door Hypothesis at the FCC." American Journal of Political Science 23(4): 665-683.

Heinz, John P., Edward O. Laumann, Robert L. Nelson, and Robert H. Salisbury. 1997. The Hollow Core: Private Interests in National Policymaking. Cambridge, MA: Harvard University Press

Holman, Craig. 2007. "Testimony of Craig Holman, Legislative Representative, Public Citizen." House Committee on Oversight and Government Reform, 13 February 2007.

Honest Leadership and Open Government Act. 2007. Public Law 110-81

Koger, Greg. 2010. Filibustering: A Political History of Obstruction in the House and Senate. Chicago: University of Chicago Press.

Kousser, Thad, Jeffrey Lewis, and Seth Masket. 2007. "Ideological Adaptation? The Survival Instinct of Threatened Legislators." Journal of Politics 69: 828-843. 
LaPira, Tim and Herschel F. Thomas III. 2014. "Revolving door lobbyists and interest representation." Interest Groups and Advocacy. 3:4-29

Lazarus, Jeffrey and Amy McKay. 2012. "Consequences of the Revolving Door: Evaluating the Lobbying Success of Former Congressional Members and the Staff." Paper presented at the Annual meeting of the Midwest Political Science Association. Chicago, IL.

Leech, Beth. 2013. Lobbyists at Work. New York: Apress.

Lobbying Disclosure Act. 1995. 2 U.S.C., Section 1605

Poole, Keith and Howard Rosenthal. 2000. Congress: A Political-Economic History of Roll Call Voting. New York, NY: Oxford University Press.

Rohde, David W. 1991 Parties and Leaders in the Postreform House. Chicago: University of Chicago Press.

Rothenberg, Larry and Mitchell S. Sanders. 2000. "Severing the Electoral Connection: Shirking in the Contemporary Congress." American Journal of Political Science 44: 310-319.

Salisbury, Robert H., Paul, Johnson, John P. Heinz, Edward O. Laumann, and Robert L. Nelson. 1989. "Who You Know versus What You Know: The Uses of Government Experience for Washington Lobbyists." American Journal of Political Science. 33:175-195

Savage, James D. 1991. "Saints and Cardinals in Appropriations Committees and the Fight against Distributive Politics." Legislative Studies Quarterly 16: 329-347.

Shepsle, Ken and Barry Weingast. 1987. "The Institutional Foundations of Committee Power." American Political Science Review. 81: 85-104.

Smith, Steven S. 2014. The Senate Syndrome: The Evolution of Procedural Warfare in the Modern U.S. Senate. Norman: University of Oklahoma Press.

Vidal, Jordi Blanes I, Mirko Draca and Christian Fons-Rosen. 2012. "Revolving Door Lobbyists." The American Economic Review 102: 3731-3748. 
Figure 1a

Members departing House and Senate, 1976-2012

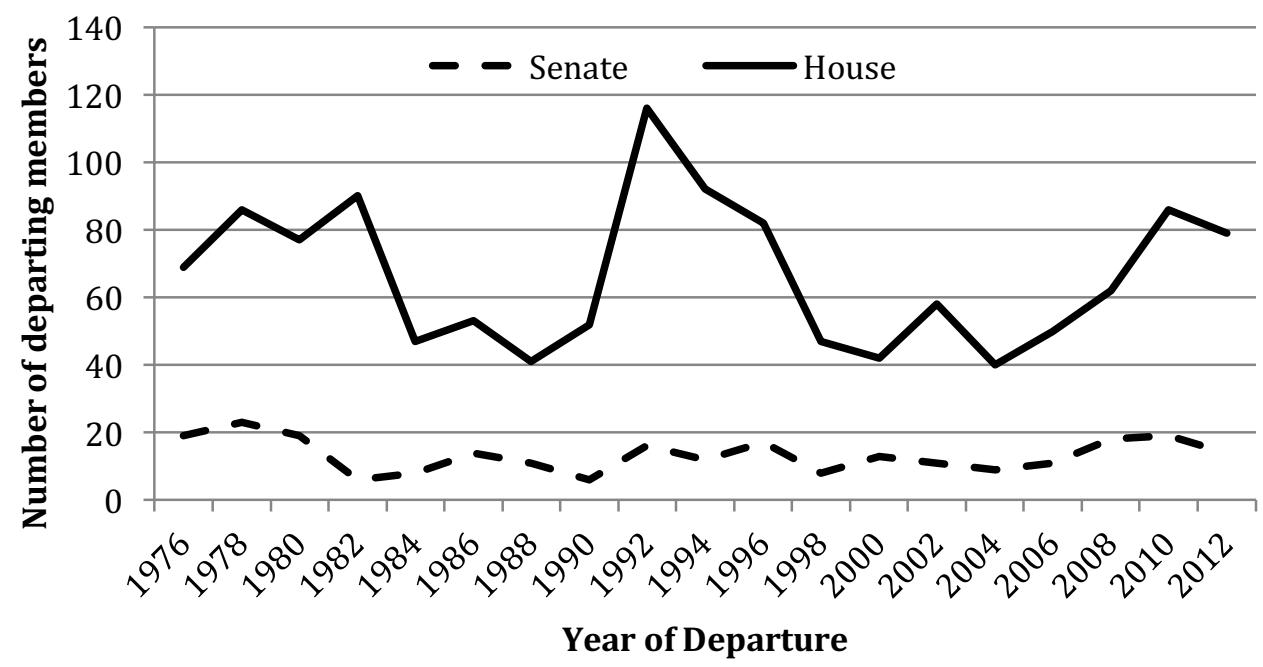

Figure $1 b$

Percent of retirees from each year registering as lobbyists, 1976-2012

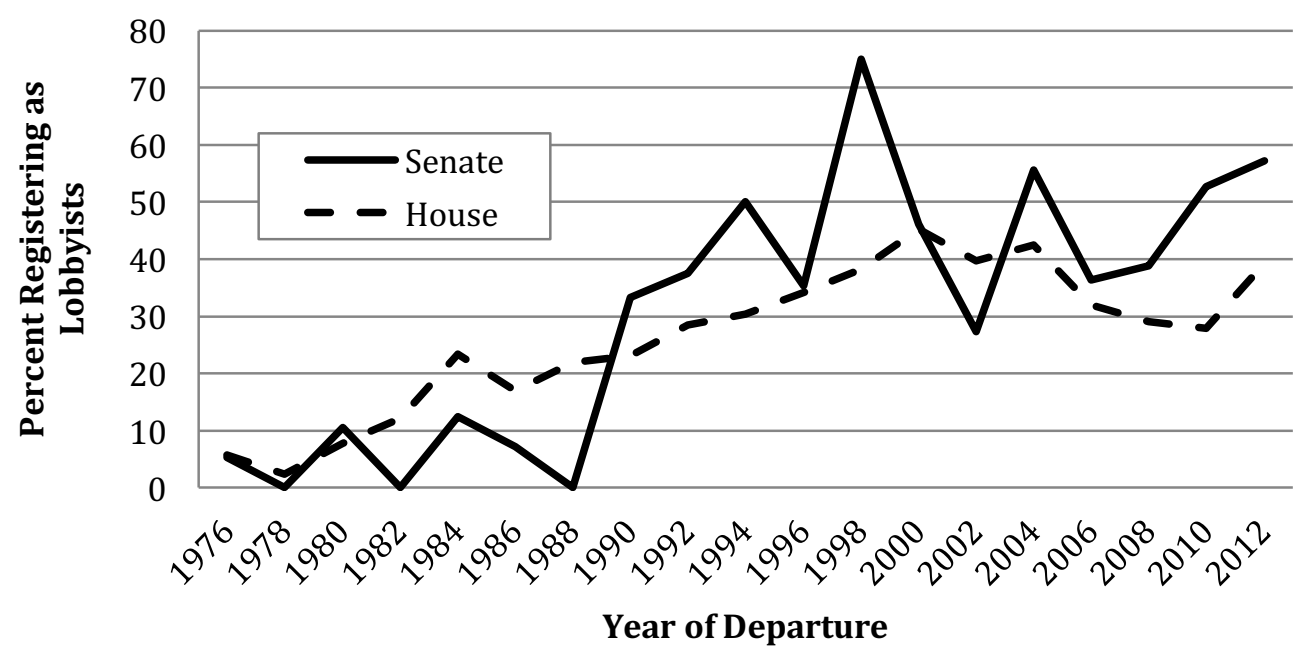


Figure 2

Former House Members Becoming Lobbyists, Members Leaving Office 1976-2012 ( $\mathrm{N}=1275)$

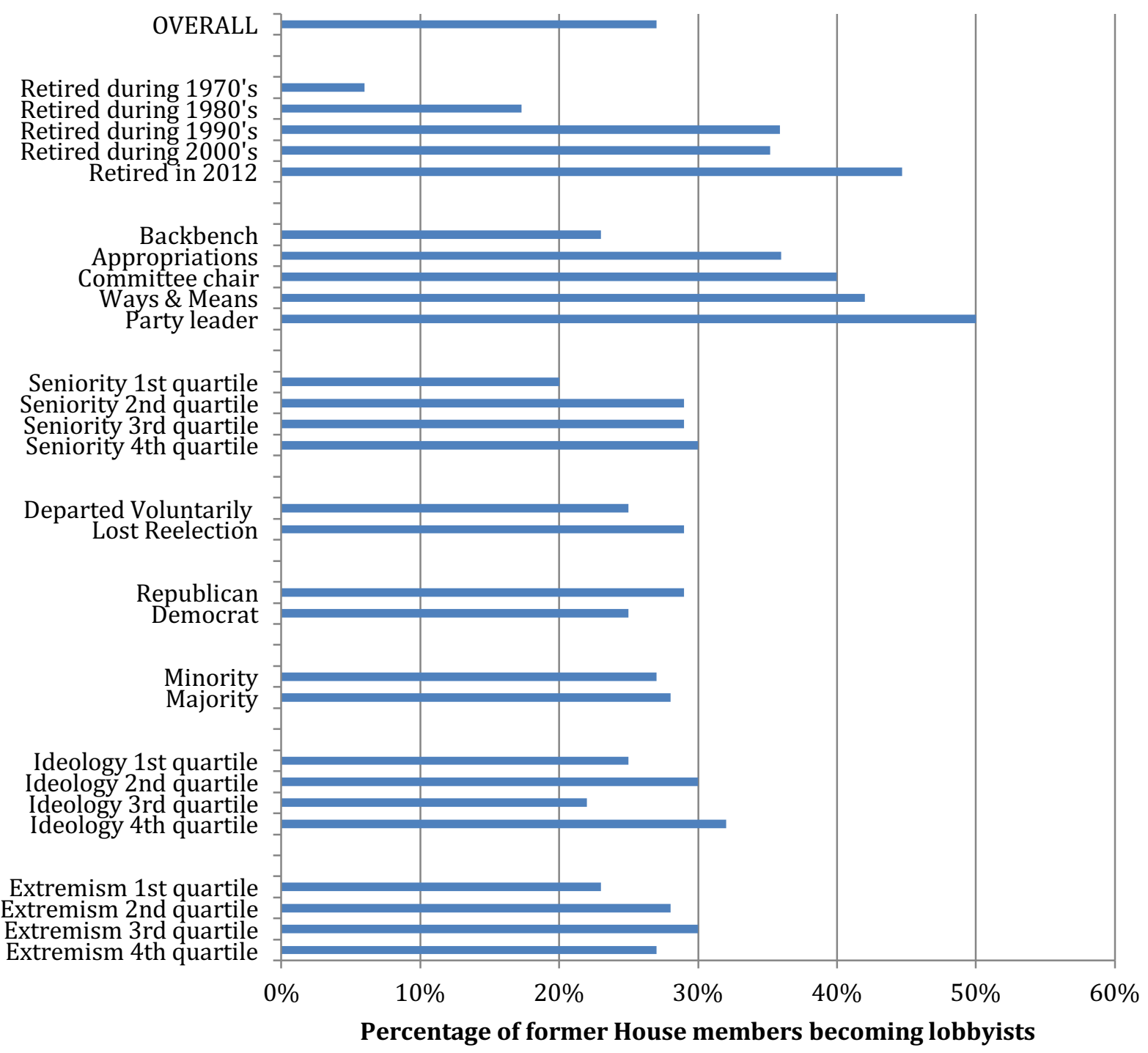


Figure 3

Former Senators Becoming Lobbyists,

Members Leaving Office 1976-2012 (N = 254)

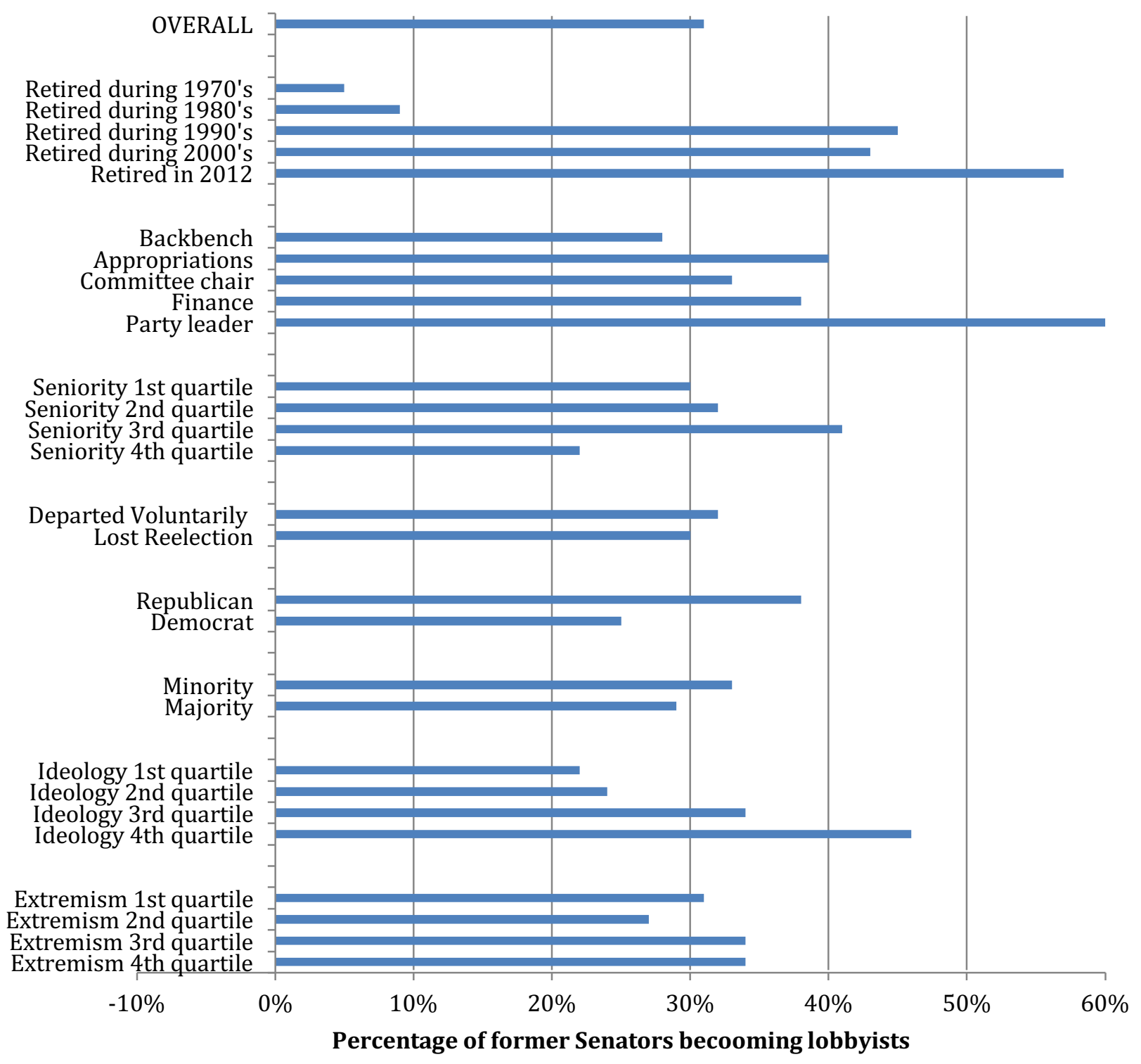


Figure 4

Years Between Leaving Congress and Registering as a Lobbyist

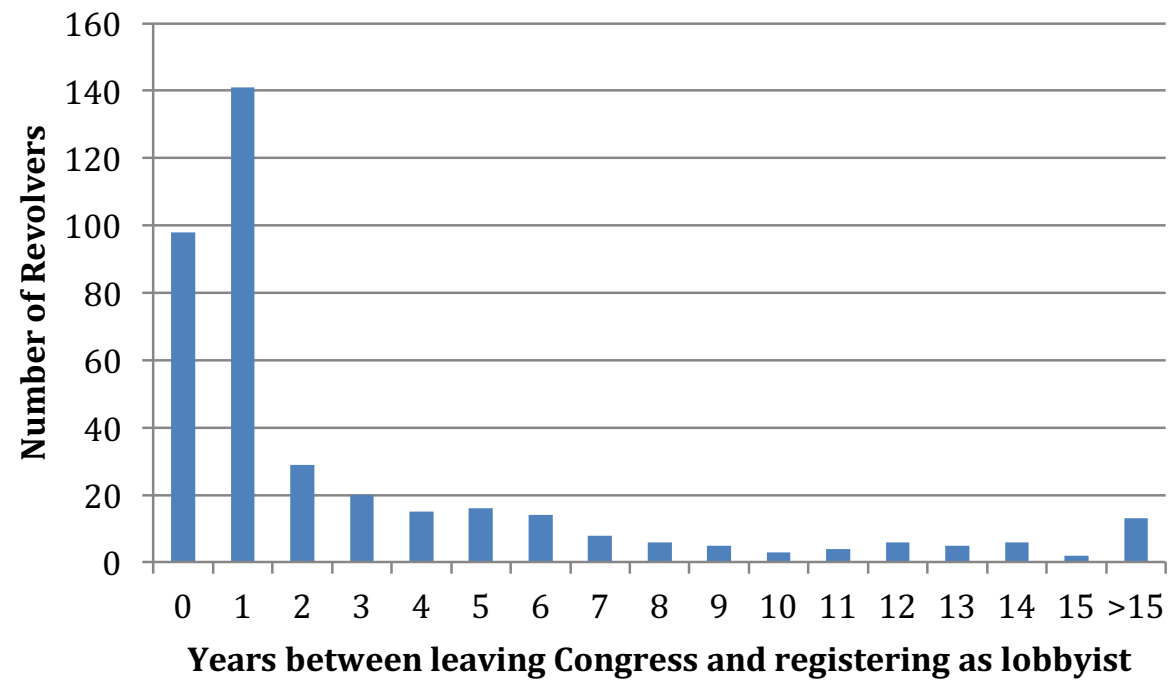


Table 1

Descriptive Statistics

\begin{tabular}{l|cccc|cccc|} 
& \multicolumn{5}{|c|}{ House } & \multicolumn{5}{c|}{ Senate } \\
& Minimum & Maximum & S.D. & Mean & Minimum & Maximum & S.D. & Mean \\
\hline Lobbyist & 0 & 1 & .433 & .249 & 0 & 1 & .455 & .291 \\
Lost last election & 0 & 1 & .483 & .368 & & & & \\
Democrat & 0 & 1 & .498 & .551 & 0 & 1 & .500 & .514 \\
Extremism & .001 & 1.013 & .191 & .351 & & & & \\
DW-NOMINATE & & & & & -.768 & .900 & .388 & -.007 \\
Committee Chair & 0 & 1 & .221 & .515 & 0 & 1 & .470 & .326 \\
Party Leader & 0 & 1 & .104 & .011 & 0 & 1 & .243 & .063 \\
Ways \& Means & 0 & 1 & .291 & .093 & 0 & 1 & .420 & .228 \\
Appropriations & 0 & 1 & .322 & .117 & 0 & 1 & .441 & .264 \\
Seniority & 1 & 53 & 8.90 & 12.2 & 1 & 52 & 10.4 & 15.7 \\
Age & 29 & 89 & 11.9 & 55.8 & 36 & 100 & 11.1 & 62.7
\end{tabular}


Table 2

Logit Estimation of Former House Members Becoming Lobbyists

\begin{tabular}{|c|c|c|c|}
\hline & Full Sample & Democrats & Republicans \\
\hline Lost last election & $\begin{array}{l}-.151 \\
(.165)\end{array}$ & $\begin{array}{l}-.134 \\
(.234)\end{array}$ & $\begin{array}{l}-.089 \\
(.240)\end{array}$ \\
\hline Democrat & $\begin{array}{l}-.252 \\
(.158)\end{array}$ & -- & -- \\
\hline Extremism & $\begin{array}{l}10 . .43^{*} \\
(4.99)\end{array}$ & $\begin{array}{l}-.455 \\
(.624)\end{array}$ & $\begin{array}{r}-1.37^{*} \\
(.606)\end{array}$ \\
\hline Extremism squared & $\begin{array}{l}-4.13^{*} \\
(1.81)\end{array}$ & -- & -- \\
\hline Committee Chair & $\begin{array}{l}.952 * * \\
(.329)\end{array}$ & $\begin{array}{l}.225 \\
(.563)\end{array}$ & $\begin{array}{l}1.75^{* * *} \\
(.483)\end{array}$ \\
\hline Party Leader & $\begin{array}{l}1.27^{*} \\
(.545)\end{array}$ & $\begin{array}{l}.574 \\
(.856)\end{array}$ & $\begin{array}{l}2.40 * * \\
(.838)\end{array}$ \\
\hline Ways \& Means & $\begin{array}{l}.761 * * \\
(.234)\end{array}$ & $\begin{array}{l}.724^{*} \\
(.350)\end{array}$ & $\begin{array}{l}.811^{* *} \\
(.309)\end{array}$ \\
\hline Appropriations & $\begin{array}{l}.624 * * \\
(.215)\end{array}$ & $\begin{array}{l}.315 \\
(.297)\end{array}$ & $\begin{array}{l}1.05 * * * \\
(.322)\end{array}$ \\
\hline Seniority (logged) & $\begin{array}{l}.761^{* * *} \\
(.157)\end{array}$ & $\begin{array}{l}.877 * * * \\
(.224)\end{array}$ & $\begin{array}{l}.667 * * \\
(.227)\end{array}$ \\
\hline Age & $\begin{array}{l}.119^{\wedge} \\
(.164)\end{array}$ & $\begin{array}{l}.165^{\wedge} \\
(.090)\end{array}$ & $\begin{array}{l}.080 \\
(.101)\end{array}$ \\
\hline Age squared & $\begin{array}{l}-.002 * * \\
(.001)\end{array}$ & $\begin{array}{l}-.002 * \\
(.001)\end{array}$ & $\begin{array}{l}-.001 \\
(.001)\end{array}$ \\
\hline Year counter & $\begin{array}{l}.078 * * * \\
(.008)\end{array}$ & $\begin{array}{l}.078 * * * \\
(.010)\end{array}$ & $\begin{array}{l}.074 * * \\
(.012)\end{array}$ \\
\hline Constant & $\begin{array}{l}3.78 * * * \\
(3.78)\end{array}$ & $\begin{array}{c}-12.08 * * * \\
(2.84)\end{array}$ & $\begin{array}{l}-8.21 * * \\
(2.82)\end{array}$ \\
\hline $\begin{array}{l}\text { N } \\
\text { Log likelihood } \\
\text { Pseudo R-squared }\end{array}$ & $\begin{array}{r}1126 \\
-556.7 \\
.154 \\
\end{array}$ & $\begin{array}{r}615 \\
-292.7 \\
.160 \\
\end{array}$ & $\begin{array}{l}511 \\
-261.5 \\
.152 \\
\end{array}$ \\
\hline
\end{tabular}

$* \mathrm{p}<.05 ; * * \mathrm{p}<.01 ; * * * \mathrm{p}<.001 ;$ two tailed tests. 
Table 3

Logit Estimation of Former Senators Becoming Lobbyists

\begin{tabular}{|c|c|c|c|}
\hline & Full Sample & Democrats & Republicans \\
\hline Democrat & $\begin{array}{l}.428 \\
(.663)\end{array}$ & -- & -- \\
\hline DW-Nominate & $\begin{array}{l}1.14 \\
(.863)\end{array}$ & $\begin{array}{c}1.71 \\
(1.56)\end{array}$ & $\begin{array}{c}1.12 \\
(1.11)\end{array}$ \\
\hline Committee Chair & $\begin{array}{l}.255 \\
(.506)\end{array}$ & $\begin{array}{l}1.24 * \\
(.732)\end{array}$ & $\begin{array}{l}-.560 \\
(.748)\end{array}$ \\
\hline Party Leader & $\begin{array}{l}1.87^{*} \\
(.745)\end{array}$ & $\begin{array}{l}4.21 * * * \\
(1.00)\end{array}$ & $\begin{array}{r}.578 \\
(1.00)\end{array}$ \\
\hline Finance & $\begin{array}{l}-.362 \\
(.437)\end{array}$ & $\begin{array}{l}-.661 \\
(.645)\end{array}$ & $\begin{array}{l}-.212 \\
(.634)\end{array}$ \\
\hline Appropriations & $\begin{array}{l}.618 \\
(.382)\end{array}$ & $\begin{array}{l}.576 \\
(.599)\end{array}$ & $\begin{array}{l}.709 \\
(.529)\end{array}$ \\
\hline Seniority & $\begin{array}{l}.108 \\
(.073)\end{array}$ & $\begin{array}{l}.013 \\
(.106)\end{array}$ & $\begin{array}{l}.226^{*} \\
(.106)\end{array}$ \\
\hline Seniority squared & $\begin{array}{l}-.003 * \\
(.0017)\end{array}$ & $\begin{array}{l}-.003 \\
(.003)\end{array}$ & $\begin{array}{l}-.005^{*} \\
(.002)\end{array}$ \\
\hline Age & $\begin{array}{c}.474 * \\
(.194)\end{array}$ & $\begin{array}{l}.882 * \\
(.375)\end{array}$ & $\begin{array}{c}.351 \\
(.313)\end{array}$ \\
\hline Age squared & $\begin{array}{l}-.004 * * \\
(.002)\end{array}$ & $\begin{array}{l}-.007 * \\
(.003)\end{array}$ & $\begin{array}{l}-.003 \\
(.006)\end{array}$ \\
\hline Year counter & $\begin{array}{l}.213 * * * \\
(.036)\end{array}$ & $\begin{array}{l}.207 * * * \\
(.052)\end{array}$ & $\begin{array}{l}.241 * * * \\
(.062)\end{array}$ \\
\hline Constant & $\begin{array}{c}-37.6 * * * \\
(7.92)\end{array}$ & $\begin{array}{l}-48.4 * * * \\
(14.8)\end{array}$ & $\begin{array}{l}-36.8^{* *} \\
(13.4)\end{array}$ \\
\hline $\mathrm{N}$ & 235 & 117 & 118 \\
\hline Log likelihood & -107.5 & -45.67 & -56.4 \\
\hline Pseudo R-squared & .265 & .303 & .280 \\
\hline
\end{tabular}


Table 4

Revolving Door Lobbyists’ First Employers, 1976-2012

\begin{tabular}{c|cc} 
& House of Representatives & Senate \\
\hline \multirow{2}{*}{ Lobbying Firm } & 255 & 71 \\
Non-Profit & $(78.5 \%)$ & $(86.6 \%)$ \\
Corporation & 22 & 2 \\
& $(6.8 \%)$ & $(2.5 \%)$ \\
Trade Association & 28 & 7 \\
& $(8.6 \%)$ & $(8.5 \%)$ \\
& 19 & 2 \\
& $(5.8 \%)$ & $(2.5 \%)$
\end{tabular}




\section{Notes}

${ }^{1}$ Since 1995 , to be required to register as lobbyists, a person must spend (i.e., be paid) at least $\$ 3000$ per quarter and 20percent or more of her time lobbying for a single client, where lobbying is defined as "lobbying contacts and any efforts in support of such contacts, including preparation or planning activities, research and other background work that is intended, at the time of its preparation, for use in contacts and coordination with the lobbying activities of others," (Senate Office of Public Records 2011, p. 4; the House uses the same definition). Former Members of Congress frequently serve as "consultants" at law firms (which, in Washington, are all lobbying firms) and do not meet the threshold of being required to register. (Lobbying Disclosure Act 1995; Honest Leadership and Open Government Act 2007; Foreign Agents Registration Act 1938).

2 Prior to 1976, very few former members of Congress register as lobbyists. Even within our dataset, prior to 1980 only one of 42 departing senators (2 percent) and six of 155 departing House members ( 4 percent) registers as lobbyists. This seemingly low rate is likely to underreport lobbying activity by former members, because the Regulation of Lobbying Act of 1946 limited registration requirements to persons who collect money for the "principal purpose" of influencing the passage or defeat of legislation. In 1954, the Supreme Court further eased the requirement by not defining "principal purpose" and not treating communication with congressional staff as attempts to influence legislation.

${ }^{3}$ The year 1992 was also the year of the House Bank scandal, and as well was the last year members of Congress could convert unused campaign money into personal use; these trends furthercontribute to the exceptional number of departures that year.

${ }^{4}$ Also, House members who became senators are not included. These members enter our dataset only as former senators if and when they depart that chamber.

${ }^{5}$ Owing to the loopholes mentioned above, there is reason to believe that CRP may tend to undercount the number of revolving-door lobbyists. This affects our results only if the unidentified members are systematically different from the identified members in the characteristics we describe in our variables. We have no reason to believe this is so.

${ }^{6}$ We recognize the limitations of comparing DW-NOMINATE scores across congresses, but believe that they serve as a reasonable proxy for member ideology.

${ }^{7}$ Strictly speaking, these are not mutually exclusive groups since the chairs of these committees are coded as both chairs and members of their committees. However, we treat them as such for the purpose of this analysis.

${ }^{8}$ Many if not most revolvers have registered as lobbyists who are employed by several different employers. We focus on the first one to simplify the coding scheme, but also because a case can be made that the first employer is the most important one from a normative standpoint. We argue that a member becomes a lobbyist to exploit her extant social connections within Congress, and those social connections will be strongest immediately upon the member's departure from Congress. They will only get weaker over time, as the former member's friends and colleagues themselves depart the chamber. Thus, each member's first employer reaps the strongest benefit of the member's social connections. Additionally, to the extent the prospect of future employment motivates a member of Congress to behave differently in his last term of office, the benefitting employer will be the first one to hire the member after he departs Congress. 